This item was submitted to Loughborough's Research Repository by the author.

Items in Figshare are protected by copyright, with all rights reserved, unless otherwise indicated.

\title{
Penicillin G solubilisation into AOT reverse micelles
}

PLEASE CITE THE PUBLISHED VERSION

PUBLISHER

(C) Elsevier

VERSION

AM (Accepted Manuscript)

LICENCE

CC BY-NC-ND 4.0

REPOSITORY RECORD

Mohd-Setapar, Siti H., Richard J. Wakeman, and E.S. Tarleton. 2009. "Penicillin G Solubilisation into AOT Reverse Micelles". figshare. https://hdl.handle.net/2134/4958. 
This item was submitted to Loughborough's Institutional Repository (https://dspace.lboro.ac.uk/) by the author and is made available under the following Creative Commons Licence conditions.

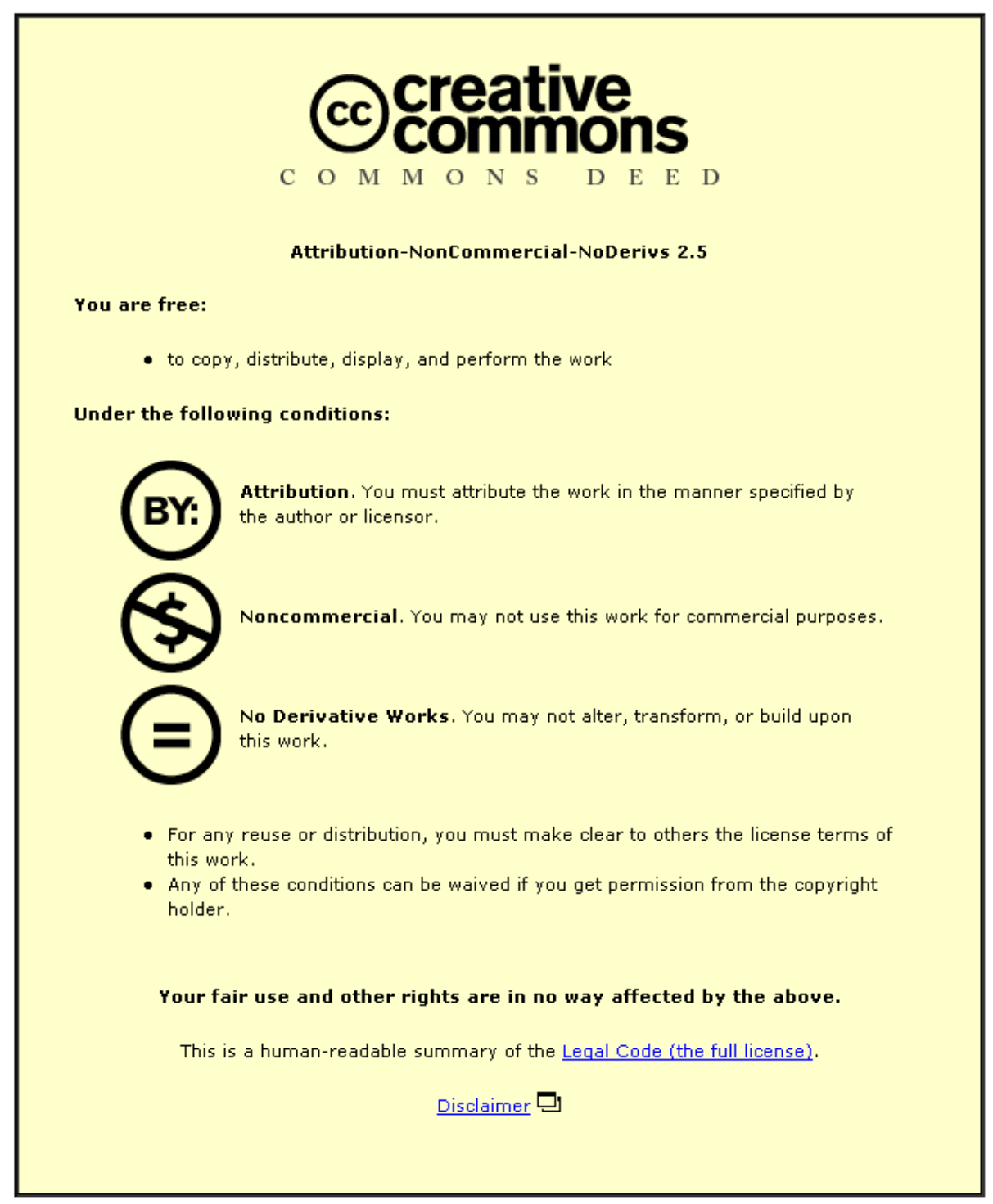

For the full text of this licence, please go to: http://creativecommons.org/licenses/by-nc-nd/2.5/ 
PENICILLIN G SOLUBILISATION INTO AOT REVERSE MICELLES

\author{
S.H. Mohd-Setapar, R.J. Wakeman and E.S. Tarleton (e.s.tarleton@lboro.ac.uk) \\ Advanced Separation Processes Group, Department of Chemical Engineering, Loughborough \\ University, Loughborough, Leicestershire, LE11 3TU, UK.
}

\begin{abstract}
Extraction of penicillin $\mathrm{G}$ from an aqueous phase into an organic phase containing AOT reverse micelles has been investigated. The extraction is influenced by the initial penicillin $G$ concentration, the salt type and concentration in the aqueous phase, $\mathrm{pH}$, and surfactant concentration. The results show that penicillin is an interfacially active compound that interacts with AOT, with the interfacial association being dependent on both $\mathrm{pH}$ and surfactant concentration. When the concentration ratio $[P]_{a q} /[S]$ is high precipitation of the penicillin occurs. The distribution coefficient favours transfer of the penicillin into the reverse micelles at moderate AOT concentrations. The distribution coefficient at infinite dilution, $K^{\infty}$, is shown to be a function of both $\mathrm{pH}$ and surfactant concentration; similar trends in the value of $K^{\circ}$ were observed at different $\mathrm{pH}$ values; $K^{\infty}$ decreases as the surfactant concentration is increased. Reverse micelle formation affects the volume of water transferred into the organic phase; from measurements of the water transferred, the size of the reverse micelles was estimated to be about $3 \mathrm{~nm}$ and the number of AOT molecules per reverse micelle about 360.
\end{abstract}

\title{
KEYWORDS
}

Anionic surfactant, extraction, partition coefficient, penicillin, reverse micelle, solubilisation, water content.

\section{INTRODUCTION}

Penicillin G, also known as benzyl penicillin, is a widely used antibiotic that has also been used as a raw material for semi-synthetic penicillin [1]. Various separation methods such as solvent extraction, ion-exchange, chromatography, crystallisation, or a combination of these, have been used for the recovery of antibiotics, however solvent extraction due to its effectiveness and favourable economics is the most widely used [2]. Solvent extraction has several difficulties which can cause problems such as final product contamination, low extraction yield, clogging of equipment, and high solvent losses $[1,3,4]$. Therefore new separation techniques have been studied to overcome the difficulties experienced whilst using conventional solvent extraction for penicillin G. Some of the techniques that have been the subject of experimental studies include ultrafiltration and nanofiltration [3,5], liquid surfactant membranes [6], and reactive extraction [1].

Separation processes using reverse micelles are based on conventional liquid-liquid extraction techniques. They are easy to scale up, have a high efficiency, can be made selective, have a low energy demand, and can be operated continuously [7,8,10-14]. They can also offer moderate thermal conditions for processing of biomaterials $[5,9]$. The method is a kind of solvent extraction using reverse micelles as the extractant [10]. Reverse micelles, also known as water-in-oil microemulsions, consist of three components: amphiphilic surfactant molecules, an aqueous phase, and a non-polar organic solvent. The polar heads of the surfactant molecules are directed towards the interior of a water-containing sphere, whereas the aliphatic tails are oriented toward the non-polar organic phase. Many authors have investigated the partitioning of proteins between two immiscible liquids, and the considerable success of protein partitioning has provided the motivation for using the technique for antibiotics; in our case penicillin G. Reverse micelles have 
the ability to extract a variety of biomolecules such as proteins[10,11,15-19] and enzymes[16,19] into nanometre-size water pools surrounded by a monolayer of surfactant.

To date most research on the purification of antibiotic molecules has focussed on those dissolved in an aqueous solvent. For example, Nabais and Cardoso [3] studied the purification of penicillin $G$ from fermentation broth by ultrafiltration, and Hu and Gulari [12] studied the extraction of aminoglycoside antibiotics such as neomycin and gentamycin using reverse micelles. These authors did not give consideration to modelling of partitioning of the antibiotic between the phases, although thermodynamic studies are important for designing downstream processing [20]. Although thermodynamic models have been applied to protein solubilisation into reverse micelles [20-26], there does not seem to have been any thermodynamic studies of penicillin G solubilisation. The apparent success of research on protein extraction from the aqueous phase using reverse micelles provides motivation to study the solubilisation of penicillin $G$, and in this work we investigate the parameters that affect solubilisation of penicillin $\mathrm{G}$ molecules into reverse micelles that lie in the organic phase.

\section{MATERIALS AND METHODS}

Reagent grade sodium di-2-ethylhexyl sulfosuccinate (AOT) was used as the surfactant, the organic solvent used for the reversed micelles was analytical grade isooctane, and the biomolecule was penicillin $\mathrm{G}$ sodium salt. $\mathrm{CaCl}_{2}$ and $\mathrm{KCl}$ were used as salts in the aqueous phase. All chemicals were supplied by Sigma Aldrich UK and were used as received. All experiments were conducted at a temperature of $23 \pm 1^{\circ} \mathrm{C}$.

$5 \mathrm{ml}$ of aqueous solution containing penicillin $\mathrm{G}$ and $\mathrm{KCl}$ was contacted with an equal volume of isooctane containing AOT; the phase transfer experiments are shown diagrammatically in Figure 1. In a sequence of experiments different AOT concentrations, $\mathrm{pH}$, and penicillin $\mathrm{G}$ concentrations were used. The $\mathrm{pH}$ of the aqueous phase was adjusted using either $\mathrm{NaOH}$ or $\mathrm{KOH}$. The solutions were then mixed for 10 minutes using a magnetic stirrer at $400 \mathrm{rpm}$. Higher stirrer speeds and longer stirring periods were not used since a stable emulsion formed under those conditions. The mixture was left for the phases to separate. After $24 \mathrm{~h}$ of settling (some samples needed more than $24 \mathrm{~h}$ to produce a clear interface between the aqueous and organic phases), samples of the organic phase were removed carefully using a pipette or syringe. For each experiment a blank solution was prepared by contacting an aqueous solution without penicillin $G$ with an equal volume of initial micellar solution. After settling, all samples of both phases were transparent to the naked eye. All experiments were replicated from two to four times in order to assess the reproducibility of the results.

The concentration of penicillin $G$ in the separated organic and aqueous phases was measured using the Kjeldahl method. The concentration of penicillin $G$ in the organic phase was determined using a mass balance. A Buchi Nitrogen Determination System (consisting of a distillation unit, a scrubber unit, and a digestion unit) was used to measure the nitrogen content of the samples; since nitrogen existed in only the penicillin $G$, the nitrogen contents were calibrated against the penicillin $\mathrm{G}$ concentration. The water content in the reverse micellar phase was measured using a Karl Fisher (KF) titrator (Mitsubishi Kasei Corp.). The readings from the KF titrator, given as percent weight of water in the sample, were then converted to the water uptake, $W_{o}$, which is the molar ratio of water to surfactant in the organic phase, $\left[\mathrm{H}_{2} \mathrm{O}\right] /[\mathrm{AOT}]$. Surface tension measurements were performed using a Wilhelmy Ring connected to a tensiometer (White Electrical Instrument Co. Ltd).

\section{THERMODYNAMIC FRAMEWORK FOR SOLUBILISATION}


Brandani et al. [25] developed an adsorption model that consisted of an aqueous phase in equilibrium with an organic phase with many identical sites made up of reverse micelles onto each of which one molecule of the adsorbing material (solute) can be entrapped. The concentration of solute in the reverse micelle can then be expressed as:

$[P]_{r m+o . f}=\frac{a b[S][P]_{a q . f}}{1+b[P]_{a q . f}}$

where $a$ and $b$ are adjustable parameters; $b$ is a parameter characteristic of the inner surface of reversed micelles, the solute, and the temperature, but it is independent of $[P]_{\text {aq.f. }}[S]$ is the concentration of the surfactant. Using this model, the distribution coefficient depends on both [S] and $[P]_{\text {aq.f }}$ and can be written as:

$K=\frac{[P]_{r m+o . f}}{[P]_{\text {aq. }}}=\frac{a b[S]}{1+b[P]_{\text {aq.f }}}$

At infinite dilution $[P]_{\text {aq.f }} \rightarrow 0$ and

$$
K^{\infty}=a b[S]
$$

or

$$
\ln K^{\infty}=\ln a+\ln b+\ln [S]
$$

A slightly different equation based on the mass-action principle was derived by Woll and Hatton [27] which indicated a pH dependency:

$$
\ln K^{\infty}=\ln a+\ln b+(c+d . p H) \ln [S]
$$

This model assumed a pseudo-chemical equilibrium for complexation of protein molecules with the hydrophobic tails of reverse micelles as empty sites. Also using the mass-action principle, Rabie and Vera [22] developed an ion exchange model for protein partitioning, based on the assumption that at equilibrium the concentration of protein in both the aqueous and reverse micellar phases are the same and that the activities of components in a solution are equal to their concentration.

Other models using vacancy solution theory based on surface pressure have been derived. On the premise that one vacancy solution represents the aqueous phase and the other the reverse micellar phase, Haghtalab and Osfouri [20] incorporated surface pressure to model protein adsorption in reverse micelles and the non-ideality of the system was expressed in terms of the Wilson activity coefficient model. The concentration of protein remaining in the aqueous phase was obtained as

$$
[P]_{\text {aq.f }}=\left[\frac{1}{b} \frac{\theta_{1}}{1-\theta_{1}}\right] f\left(\Lambda_{12}, \Lambda_{21}, \theta_{1}\right)
$$

where $\Lambda_{12}$ and $\Lambda_{21}$ are Wilson parameters and $\theta_{1}$ is the fractional coverage of the protein molecules. The term in square brackets is exactly the same as the Langmuir equation, and $f\left(\Lambda_{12}\right.$, $\Lambda_{21}, \theta_{1}$ ) may be regarded as a correction factor to the Langmuir isotherm. Their data showed that the values of the Wilson parameters are $\mathrm{pH}$ dependent, which could reasonably be expected since the surface charge on the protein (BSA in their case) varied from negative at $\mathrm{pH}<\mathrm{pl}$ to positive at $\mathrm{pH}>\mathrm{pl}$. 


\section{RESULTS AND DISCUSSION}

At equilibrium, the penicillin is distributed between four solubilisation sites: (i) the aqueous phase continuum, (ii) the water pools lying within the reverse micelles in the organic continuum, (iii) the organic continuum, and (iv) at the reversed micellar interface between the organic phase and the water pool (see Figure 2).

The critical micelle concentration (CMC), the lowest concentration of surfactant needed for reversed micelle formation, of the AOT in isooctane was measured using a tensiometer and the results are shown in Figure 3. For the experiments without penicillin, the AOT was mixed into a sample of isooctane and the surface tension of the mixture measured. For those experiments where penicillin was present, the penicillin was extracted from an aqueous solution and the organic and aqueous solutions separated before the surface tension of the organic phase was measured. The concentration of penicillin is therefore different for each data point, and corresponds to its equilibrium partitioning between the phases.

Use of a stirrer speed greater than 400 rpm caused formation of an emulsion that made clear phase separation difficult. In some cases the emulsion was short lived and disappeared after $24 \mathrm{~h}$ settling time. The effect of the settling period on the concentration of penicillin $\mathrm{G}$ in the organic phase at different AOT concentrations was studied. From our observations there were no significant differences between $24 \mathrm{~h}$ and one week settling times, indicating that the penicillin solubilisation had reached an equilibrium state; more than $24 \mathrm{~h}$ settling time did not have an effect on the extraction efficiency.

\section{Interfacial Association and Phase Volume Changes}

When experiments were carried out using different AOT concentrations, there was an increase in the volume of the organic phase that was proportionate to a decrease of the aqueous phase volume, as shown in Figure 4. At AOT concentrations less than the CMC, there was little or no visible increase in the volume of the organic phase. When the AOT concentration was increased to above about $40 \mathrm{~g} / \mathrm{l}$, the effect of reverse micelle formation showed itself by an increase in the volume of the organic phase as water was transferred into the reverse micellar structures.

Leodidis and Hatton [26] suggested, based on arguments stemming from Gibbs free energy of transfer of a solute from water to the surfactant interface, that an interfacial partition coefficient could be calculated on the basis of solute concentration measurements of the initial and final aqueous phases. For a solute that does not associate with the revere micellar interface $[P]_{a q . f}=$ $[P]_{\text {aq.i, }}$ and deviations from this line imply interfacial association of the solute. Figure 5 is a plot of $[P]_{\text {aq. }}$ versus $[P]_{\text {aq.i }}$ data for the AOT-penicillin system, and illustrates that penicillin $G$ is an interfacially active molecule at all AOT concentrations. The slope of the data indicates there is least surface activity at an AOT concentration of $88 \mathrm{~g} / \mathrm{l}$; at an AOT concentration of $445 \mathrm{~g} / \mathrm{l}$ the deviation of the data is farthest from the $[\mathrm{P}]_{\text {aq. }}=[\mathrm{P}]_{\text {aq. }}$ line, indicating greater surface activity.

Leodidis and Hatton [26] also showed that an interfacially active molecule can be identified through a plot of molecule transfer (in their case amino acid) $\left(t_{a}\right)$ versus the fractional water transfer $\left(t_{w}\right)$ to the organic phase. Simple mass balances show that $t_{a}$ and $t_{w}$ are given by:

$$
t_{w}=1-\frac{V_{a q . f}}{V_{a q . i}}
$$

and 
$t_{a}=1-\frac{[P]_{a q . f} V_{a q . f}}{[P]_{a q . i} V_{a q . i}}$

$t_{w}$ can be varied by changing the $\mathrm{pH}$ or the salt content of the aqueous phase or the AOT concentration in the initial organic phase. The penicillin transfer, $t_{a}$, is plotted against the fractional water transfer, $t_{w}$, on Figure 6 , which gives further support to penicillin being interfacially active in the presence of AOT. $t_{w}$ indicates the increase in organic phase volume; when $t_{w}$ is finite $V_{\text {aq.f }}<$ $V_{a q . i}$ equations (7) and (8) give, when $t_{a}>t_{w}$

$$
t_{a}-t_{w}=\left(1-t_{w}\right)\left(1-\frac{[P]_{a q . f}}{[P]_{a q, i}}\right)
$$

and it is a requirement that $[P]_{\text {aq.f }}<[P]_{\text {aq.i. }}$ The vertical displacement of the experimental data from the $t_{a}=t_{w}$ line is a measure of the strength of interfacial association; Figure 6 shows that penicillin $\mathrm{G}$ is slightly more interfacially active at surfactant concentrations of $267 \mathrm{~g} / \mathrm{l}$ and $88 \mathrm{~g} / \mathrm{l}$ than surfactant concentrations $445 \mathrm{~g} / \mathrm{l}$ and $333 \mathrm{~g} / \mathrm{l}$, and also that interfacial association is dependent on both $\mathrm{pH}$ and surfactant concentration. Similar trends were observed for the AOT-amino acid system by Leodidis and Hatton [26].

\section{Partitioning of Penicillin G Between the Organic and Aqueous Phases}

Penicillin $\mathrm{G}$ solubilisation into the reverse micellar phase is influenced by parameters that are related to the organic phase such as surfactant concentration, in addition to the properties of the aqueous phase (such as $\mathrm{pH}$ and salt concentration). The motivation for using AOT as the surfactant in this study was due to its ease of forming reverse micelles, its stability in comparison with other surfactants, and that it has been used in many published studies of other systems with success $[19,28]$. Initially, the effect of AOT concentration on reverse micellar extraction was examined using an aqueous solution with $\mathrm{pH} 7.60$ and $0.1 \mathrm{M} \mathrm{KCl}$. A 'white precipitate' was observed at the interface of some samples when the surfactant concentration used was less than $0.1 \mathrm{M}$; later experiments showed that the onset of precipitate formation was dependent on the ratio of penicillin concentration $[P]_{\text {aq }}$ to surfactant concentration $[S]$. Some researchers extracting proteins found that using AOT concentrations greater than $0.1 \mathrm{M}$ caused interfacial protein precipitation [29]. The 'white precipitate' is a dispersion phenomenon that occurred when the ratio $[P]_{a d} /[S]$ was high because of low hydrophobicity in the system due to the low surfactant concentration used, which appears to be similar to protein aggregation rather than protein solubilisation into the organic phase found by others [11].

A sought after effect of the AOT concentration on penicillin extraction is to increase the amount of penicillin transferred to the reverse micellar phase. It was known that the surfactant concentration controls the number of reverse micelles and hence the capacity to solubilise biomolecules into the reverse micelle pool [19,30]. Increasing the surfactant concentration increases the number of reverse micelles [31], thus leading to improvement in their extraction capacity. Figure 7 shows that as the concentration of AOT was increased from 0 to $222 \mathrm{~g} / \mathrm{l}$, the amount of penicillin extracted into the reverse micellar phase increased. However, increasing AOT concentration from $222 \mathrm{~g} / \mathrm{l}$ to 445 $\mathrm{g} / \mathrm{l}$ the penicillin $\mathrm{G}$ in reverse micelles decreases. There is an optimum surfactant concentration of between 100 and $200 \mathrm{~g} / \mathrm{l}$ that corresponds to the maximum limit for penicillin $\mathrm{G}$ transfer into the reverse micelles. Penicillin $\mathrm{G}$ is a small biomolecule (molecular weight of $356 \mathrm{~g} / \mathrm{mole}$ ); according to Pires et al. [30], small molecules are more easily extracted to the reverse micelles using low surfactant concentration. Moreover, our experiments showed that use of AOT concentration $>445$ $\mathrm{g} / \mathrm{l}$ produced a stable emulsion (when subjected to gravity settling), making it difficult to separate and analyse. 
It was found that penicillin $\mathrm{G}$ did not dissolve in the organic phase without AOT. Since penicillin $G$ was extracted into the organic phase only when reverse micelles were present, it is assumed that the penicillin $G$ is located within their structure. The partition (distribution) coefficient, $K$, is defined by:

$$
K=\frac{[P]_{r m+o . f}}{[P]_{\text {aq.f }}}
$$

A higher value of partition coefficient indicates better solubilisation of penicillin $G$ into the reverse micelles.

Figure 8 shows that the distribution coefficient increases with increasing AOT concentration. The extent of solubilisation of penicillin into the reverse micellar phase depends on the quantity of reverse micelles, which during mixing are better dispersed in the bulk aqueous phase when more surfactant molecules are present. Haghtalab and Osfouri [20] asserted that adding more surfactant to the solution intensifies the interaction between the reverse micelles and the protein molecules (in their case) and result in the number of moles, and the maximum mole number of protein on the surface of the reverse micelles, being changed. Figure 8 shows that there is no saturation limit for the concentration of penicillin that can be transferred into the reverse micellar phase in the region $0<[P]_{\text {aq. }}<7 \mathrm{~g} / \mathrm{l}$. However, there is a concentration limit of AOT which can solubilise a maximum concentration of penicillin $G$ into reverse micelles. The partition coefficients of penicillin $\mathrm{G}$ are effectively the same at $[\mathrm{S}]=267$ and $445 \mathrm{~g} / \mathrm{l}$. This trend confirmed that penicillin $G$ is an interfacially active compound which can easily transfer to reverse micelles.

It was found that partition coefficient increases when using an higher initial concentration of penicillin in the feed (aqueous) phase as this appears to promote the penicillin solubilisation into the reverse micellar phase. A possible explanation is that at higher initial concentrations of penicillin in the aqueous phase the ion-dipole interactions between penicillin and AOT molecules are larger than ion-ion interactions between penicillin molecules.

In previous studies of protein and amino acid extraction using reversed micellar systems other researchers buffered the aqueous phase to adjust the $\mathrm{pH}[26,32,33]$. However, Wang et al. [4] pointed out that buffers can interfere with the solubilisation of biomolecules into the reverse micellar phase because the buffer anions may compete with the amino acid (in their case) to interact with the surfactant headgroup; in other work buffers were avoided because over such a wide range of $\mathrm{pH}$ values they would give the addition of an unnecessary mixture of ions to the system [34]. In this paper we have used $\mathrm{NaOH}$ and $\mathrm{HCl}$ to adjust the $\mathrm{pH}$. To examine the effect of $\mathrm{pH}$ on the partitioning of penicillin, aqueous $\mathrm{KCl}$ solutions containing $3.6 \mathrm{~g} / \mathrm{l}$ of penicillin and various $\mathrm{pH}$ values were contacted with solutions of AOT of various concentrations at volume ratios of 1:1. The results are shown in Figure 9 as a relation between the concentration of penicillin $G$ in the organic phase and the $\mathrm{pH}$ value at the equilibrium state.

From Figure 9, it is clear that for all concentrations of AOT, the results show a maximum penicillin $\mathrm{G}$ concentration in the reverse micellar phase at low $\mathrm{pH}$ values which could be attributed to the high electrostatic attraction between AOT anions and the positively charged penicillin $\mathrm{G}$ aggregates at $\mathrm{pH} \approx 1$ to 2 .

Previous studies on protein extraction have also shown that $\mathrm{pH}$ plays an important role in reverse micellar systems [8, 12, 30, 31, 35-38]. Noble and Varley [39], using protein as the biomolecule, pointed out that the $\mathrm{pH}$ of the protein and surfactant solutions could be manipulated so that the protein would exhibit a net charge opposite to that of the surfactant, thus allowing electrostatic interactions between the protein and surfactant in the different phases. Kilikian et al. [37] explained that overall protein charge is determined by the $\mathrm{pH}$ of the aqueous phase and the isoelectric point ( $\mathrm{pl}$ ) of the biomolecule used (protein, in their case). If the $\mathrm{pH}$ of the aqueous 
phase is higher than the $\mathrm{pl}$, the charge is negative, but if the $\mathrm{pH}$ is lower than the $\mathrm{pl}$, the charge is positive. Using this postulate for the anionic AOT, the penicillin $\mathrm{G}(\mathrm{pl}=2.74)$ is expected to have strong attraction with the surfactant head group at $\mathrm{pH}<2.74$. Hence, more penicillin $\mathrm{G}$ could be solubilized into the reverse micellar solution at $\mathrm{pH}<\mathrm{pl}$. From the viewpoint of industrial production of penicillin $\mathrm{G}$, extraction is carried out at $\mathrm{pH} 2.5-3.0$. Figure 9 shows that at $\mathrm{pH}>\mathrm{pl}$ a higher AOT concentration needs to be used in order to get the same concentration of penicillin $G$ in the organic phase as at $\mathrm{pH}<\mathrm{pl}$; however, one should take into account that there is an optimum AOT concentration $(222 \mathrm{~g} / \mathrm{l})$. The concentration of penicillin $\mathrm{G}$ in reverse micelles decreases dramatically when $[S]=445 \mathrm{~g} / \mathrm{l}$ is used. This raises the question of whether the $\mathrm{pH}$ can be manipulated to get better penicillin $\mathrm{G}$ extraction at low AOT concentration in an industrial application (it should be noted that penicillin broths are compositionally more complex than those used in this work, which will change the equilibria that can established in the extraction process). The use of a low surfactant concentration would be helpful because amphiphilic molecules are difficult to remove in subsequent downstream processing [18].

Ono et al. [8], using anionic surfactant DOLPA to extract haemoglobin $(\mathrm{pl}=6.8)$ found that even though the best extraction was obtained at $\mathrm{pH}<\mathrm{pl}(5.5-6.5)$, a precipitate occurred at $\mathrm{pH}<5$. They found that at the $\mathrm{pH}<<\mathrm{pl}$, the biomolecules tend to form a complex that binds to the surfactant. In this study, we observed precipitation when high initial penicillin $\mathrm{G}$ concentrations were used at low $\mathrm{pH}$. Although an extremely low $\mathrm{pH}$ range was used, at $[\mathrm{KCl}]=10 \mathrm{~g} / \mathrm{l}$ and 400 rpm stirring speed, a transparent two phase system was obtained with a clear interphase when $[P]_{\text {aq.i }}<10 \mathrm{~g} / \mathrm{l}$. From the results it appears that the $\mathrm{pH}$ effect is important for the penicillin $\mathrm{G}$ extraction, although the electrostatic contribution is also relevant for the AOT reverse micelles which achieved better binding at higher $\mathrm{pH}$ values.

Whilst some of the thermodynamic models for solubilisation suggest that there should be an effect of $\mathrm{pH}$ (for example, equation (5)), others do not (see equation (4)). In this work the dependence of the partition coefficient (see equation (10)) on penicillin concentration, AOT concentration, $\mathrm{pH}$, and salt type and concentration has been measured. When the partition coefficient, $K$, is plotted against the concentration of penicillin in the aqueous phase, $[P]_{\text {aq.f. }}$, (all other parameters being held constant) and the experimental data extrapolated back to $[P]_{\text {aq. }}=0$ line, a value for the partition coefficient at infinite dilution, $K^{\infty}$, is found. Following this procedure, the results for $\mathrm{pH} 1.65$ and 7.6 are shown in Figure 10.

The distribution coefficient at infinite dilution depends markedly on $\mathrm{pH}$ and surfactant concentration. $K^{\circ}$ increases as the surfactant concentration increases, and is higher at $\mathrm{pH} 1.65$. However, one should notice that the limitation of using a pH as low as 1.65 is that the extraction becomes troublesome due to formation of a precipitate except at very low penicillin concentrations. So whilst there is clearly a $\mathrm{pH}$ effect on $K^{\infty}$, factors have to be taken into account in a practical sense.

\section{Effects of Salt Type and Concentration}

The salt concentration of the aqueous phase influences the solubilisation of penicillin into the reverse micellar phase. The salt concentration was investigated by varying the $\mathrm{KCl}$ concentration in the aqueous phase at $\mathrm{pH}$ 7.6. When $[\mathrm{KCl}]>10 \mathrm{~g} / \mathrm{l}$ the penicillin concentration in the organic phase was found to decrease, although increasing $[\mathrm{KCl}]$ from 0 to $10 \mathrm{~g} / \mathrm{l}$ showed a significant increase of penicillin in the organic phase. A decrease of the water concentration in the micellar phase was found to accompany an increase of $[\mathrm{KCl}]$.

At $[\mathrm{KCl}]<5 \mathrm{~g} / \mathrm{l}$ almost all of the surfactant migrated to the aqueous phase and no reverse micelles were formed in the organic phase. This phenomenon was observed visually, and made addition of salt to the aqueous penicillin $G$ solution very important to avoid the formation of a stable emulsion. A minimum amount of salt is necessary to salt out the surfactant from the excess aqueous phase into the organic phase to form reverse micelles [40,41]. Reverse micelles will not form if there is 
too little salt in the aqueous phase; however, if there is too much salt, the efficiency of surfactant molecules to solubilise the penicillin $G$ molecules reduces. Wang et al. [4] reported that ionic strength is required to reduce electrostatic repulsion between the surfactant head groups, and reported that if no salt is added to the system the aggregation of surfactant and/or the surfactant and protein complex formed a coagulum and induced a phase separation problem. The solubilisation of water by an AOT reverse micellar solution in equilibrium with an aqueous phase (in both cases with and without penicillin $G$ ) was found to be a strong function of salt concentration in our experiments. Others have suggested that decreasing both biomolecule concentration and water content in the organic phase happens because of a size exclusion effect occurring with the decrease in micelle size [42, 43], asserting that a decrease in solubilisation of the enzyme with increases in ionic strength resulted from smaller micelles being formed because of the reduced interaction between the surfactant polar head group and the hydrophilic region of the enzyme.

Our experimental results showed that penicillin G could be extracted into the reverse micellar phase quantitatively over a relatively small salt concentration range. With increasing salt concentration over $10 \mathrm{~g} / \mathrm{l}$, the extent of penicillin $\mathrm{G}$ transfer decreased in spite of the $\mathrm{pH}$ being in the region where the electrostatic interaction between antibiotic and surfactant is attractive. According to Dekker et al. [29] the ionic strength of the aqueous phase determines the degree of shielding of the electrostatic potential imposed by a charged surfactant head group. They also suggested that by increasing the ionic strength the electrostatic interaction between the charged penicillin molecules and the charged surfactant head groups is reduced.

Salt type also plays an important role in the extraction of biomolecule from the aqueous to the reverse micellar phases [10,44-46]. We used two salts, $\mathrm{KCl}$ and $\mathrm{CaCl}_{2}$, dissolved in the aqueous phase and found that the concentration of penicillin $\mathrm{G}$ in the reverse micellar phase is higher when using $\mathrm{CaCl}_{2}$. This is because a divalent salt like $\mathrm{CaCl}_{2}$ leads to smaller reverse micelle droplets and the ability to solubilise more penicillin is increased. However, it was observed that when using $\mathrm{CaCl}_{2}$ the solution became more sensitive to the stirring speed and tended to emulsify more easily. This caused problems with getting a good phase separation, and even when the phases can be separated extra time was needed for the solutions to achieve equilibrium.

\section{Reverse Micelle Formation and Water Content}

The water content in the AOT/isooctane organic phase was measured using a Karl Fischer titration method after mixing with two $0.1 \mathrm{M} \mathrm{KCl}$ solutions, one with and one without penicillin $\mathrm{G}$, in order to examine the formation of reverse micelles. Figure 11 shows the water content in the organic phase before and after the mixing process. The mixing process increased the water content in the reverse micellar phase (due to the presence of the AOT). When using the same AOT concentration but without mixing there was no solubilisation of water into the organic phase. This shows that the AOT carries water to the organic phase and form reverse micelles, and that mixing is an important process to produce solubilisation of water into the organic phase. After the extraction process was accomplished, the organic phase was clear and transparent indicating that the formation of AOT reverse micelles had been achieved. It also shows that the reverse micelles transfer a large amount of water to the organic solution, and since the penicillin molecules solubilise in water but not in isooctane the reverse micelle system has the ability to extract penicillin molecules into the organic solution.

Figure 11 confirms the above and shows that the water content in the organic phase increases in proportion to the AOT concentration, and without surfactant $([S]=0)$ there is no water uptake. The water content values level off when $[S] \approx 450 \mathrm{~g} / \mathrm{l}$ indicating that the amount of water that can be carried to the reverse micellar phase by the AOT molecules is limited. At [S] $>667 \mathrm{~g} / \mathrm{l}$ the whole solution became a stable emulsion, making it is impossible to separate the penicillin molecules from the initial aqueous phase since no phase separation occurs after the mixing process. 
The water content of the micellar phase is an important parameter affecting penicillin $\mathrm{G}$ extraction into a reverse micellar system. Previous studies have shown that water content has a strong influence on protein solubilisation and subsequent functions such as the size of reverse micelles $[8,37,47]$. Those researchers used the molar ratio of water to surfactant in the micellar organic phase $\left(W_{o}\right)$ as an important parameter in understanding what affects the characteristics of the reverse micelles, such as their size. The water content analysis is also important in order to determine the structure of reverse micelles and the number of surfactant molecules per reverse micelle [47]. To examine the relationship between water content in the organic phase and penicillin transfer, an experiment was carried out to measure the water content in the organic phase in the extraction system with and without penicillin. The water content in the system without penicillin was found to be higher than that with penicillin. A similar phenomenon was observed by Ono et al. [8] who used DOLPA reverse micelles to extract haemoglobin. They suggested that water never accompanied the haemoglobin molecules when they were dissolved into the reverse micelles, because haemoglobin extraction consumes the surfactants to form empty reverse micelles. In our penicillin $G$ experiments, to fill the reverse micelles' pools in the organic phase the system without penicillin encouraged more reverse micelles containing water compared to the system containing penicillin.

The effect of the AOT concentration and the initial amount of penicillin $\mathrm{G}$ on the solubilising water was also investigated with experiments carried out at $\mathrm{pH} 7.6$ and $0.1 \mathrm{M} \mathrm{KCl}$ (there was no precipitation or emulsion observed in these experiments). The transparent interface formed, with no insoluble aggregates, indicated that the reverse micelles solubilised successfully in the organic phase. An increase in surfactant concentration from $267 \mathrm{~g} / \mathrm{l}$ to $445 \mathrm{~g} / \mathrm{l}$ caused the water uptake to increase from $25 \%$ to $35 \%$. These results agree with studies of protein extraction [9, 48, 49]. For example, Spirovska and Chaudhuri [50] showed that the percentage content of water in the organic phase increased proportionally with the surfactant concentration due to more reverse micelle molecules being solubilised in the organic phase.

To determine a reverse micelle size, other researchers have recommended equations which relate the molar ratio of water to surfactant $\left(W_{o}\right)$ values. From purely geometrical considerations and assuming the micelles to be monosized with all the surfactant located in a monolayer at the aqueous-organic interface, the reverse micelle radius (water pool radius), $r_{r m}$, is related to $W_{o}$ by [52]

$r_{r m}=\left(\frac{3 V_{\mathrm{H}_{2} \mathrm{O}}}{a_{A O T}}\right) W_{o}$

where $V_{H 2 O}$ is the volume of a water molecule (approximately $0.03 \mathrm{~nm}^{3}$ ) and $a_{A O T}$ is the surface area of the surfactant head group $\left(0.5 \mathrm{~nm}^{2}\right)$.

For [S] $>20 \mathrm{~g} / \mathrm{l}$, the experimental values of $W_{0}$ were fairly constant and found to be in the range $15.7 \leq W_{o} \leq 17.6$ and the calculated reverse micelles radii were around $3 \mathrm{~nm}$. It has been reported that with an increase of surfactant concentration, micellar size does not change for most surfactants, which is the case for AOT [52]. The results from our work are in agreement with the results of previous works which suggest that the calculated value of $r_{r m}$ varies between 1 and $3 \mathrm{~nm}$. Using the same assumptions which lie behind equation (11), and further assuming that the projected areas of the AOT head groups are packed at the micelle surface with a porosity of 0.4 , the number of AOT molecules per reverse micelle is about 360 . This lies well within the range 100-900 reported by Lye [52].

Many studies have shown that other parameters such as $\mathrm{pH}$ and salt concentration can affect the solubilisation of biomolecules into the reverse micelle phase; however, the results from the penicillin $\mathrm{G}$ extraction study here show that surfactant concentration is the most important parameter affecting the solubilisation of penicillin into the reverse micelle phase. Ichikawa et al. 
[9], extracting protein using the AOT reverse micelle system, found that even using suitable $\mathrm{pH}$ and salt concentration the extraction will not happen if insufficient AOT concentration is used. They suggested that the solubilising water provides the hydrophilic surroundings that are vital in the reverse micelle extraction process, and that the AOT molecules seemed to take part of the water solubilising agent in the process. Similar to the results from this study, they also found that the maximum water solubilisation increased with increasing surfactant concentration.

\section{CONCLUSIONS}

Experiments on the solubilisation of penicillin $\mathrm{G}$ into reverse micelles of AOT have been carried out. The results show that the concentration of penicillin $G$ in the organic phase depends primarily on the $\mathrm{pH}$ and surfactant concentration, with the salt type and concentration in the aqueous phase also being important. However, the effect of the salt type and concentration is sufficiently great to signify that extraction from a broth needs to be assessed experimentally.

The results show that penicillin $\mathrm{G}$ is an interfacially active compound that interacts with AOT, with the interfacial association being dependent on both $\mathrm{pH}$ and surfactant concentration. When the concentration ratio $[P]_{a q} /[S]$ is high, precipitation of the penicillin occurs, which limits the possible use of reverse micellar extraction at low values of $[P]_{a q}$.

The distribution coefficient favours solubilisation of the penicillin into the reverse micelles at moderate AOT concentrations. There is no saturation limit of penicillin $\mathrm{G}$ transferred into reverse micelles; there is a limit of surfactant concentration beyond which the concentration of penicillin $G$ transferred into reverse micelles remains constant. The distribution coefficient at infinite dilution, $K^{\infty}$, has been shown to be a function of both $\mathrm{pH}$ and surfactant concentration. Similar trends in the value of $K^{\infty}$ were observed at different $\mathrm{pH}$ values; $K^{\infty}$ increases as the surfactant concentration is increased. However, although $K^{\infty}$ is higher at $\mathrm{pH} 1.65$ the extraction is difficult due to precipitation when high initial penicillin concentration is used.

Reverse micelle formation affects the volume of water transferred into the organic phase (this water is held within the reverse micelles). From measurements of the water transferred, the size of the reverse micelles was estimated to be about $3 \mathrm{~nm}$ and the number of AOT molecules per reverse micelle about 360 . These values are in broad agreement with previous work using AOT to extract proteins.

\section{NOMENCLATURE}

$\begin{array}{ll}a_{A O T} & \begin{array}{l}\text { area of a surfactant head group } \\ \text { bis(2-ethylhexyl) sulfosuccinate } \\ \text { dioleyl phosphoric acid }\end{array} \\ \text { DOLPA } & \begin{array}{l}\text { distribution coefficient } \\ \text { distribution coefficient at infinite dilution }\end{array} \\ K^{\infty} & \mathrm{KCl} \text { concentration } \\ {[K C l]} & \text { final concentration of penicillin } \mathrm{G} \text { in the aqueous phase } \\ {[P]_{\text {aq.f }}} & \text { initial concentration of penicillin } \mathrm{G} \text { in the aqueous phase } \\ {[P]_{\text {aq.i }}} & \text { final concentration of penicillin } \mathrm{G} \text { in the reverse micelle organic phase } \\ {[P]_{r m+o . f}} & \text { reverse micelle radius } \\ r_{r m} & \text { surfactant concentration } \\ {[S]} & \text { fractional transfer of penicillin } \mathrm{G} \\ t_{p} & \text { fractional water transfer } \\ t_{w} & \text { final volume of aqueous phase } \\ V_{a q . f} & \text { initial volume of aqueous phase } \\ V_{a q . i} & \text { volume of a water molecule } \\ V_{H 2 O} & \end{array}$


$W_{0} \quad$ molar ratio of surfactant concentration to water concentration

$\theta_{1} \quad$ fractional coverage according to a Langmuir type isotherm

$\wedge_{i j} \quad$ Wilson parameters

\section{ACKNOWLEDGEMENTS}

The authors would like to acknowledge the financial support from the Universiti Teknologi Malaysia for the scholarship awarded to Siti Hamidah Mohd Setapar to make this study possible.

\section{REFERENCES}

1. Yang C. and Cussler E.L., 2000, Reactive extraction of penicillin $G$ in hollow-fiber and hollowfiber fabric modules, Biotechnol. Bioeng. 691, 66-73.

2. Soto A., Arce A. and Khoshkbarchi M.K., 2005, Partitioning of antibiotics in a two-liquid phase system formed by water and a room temperature ionic liquid, Sep. Purif. Tech., 44, 242-246.

3. Nabais A.M.A and Cardoso J.P., 1999, Purification of benzylpenicillin filtered broths by ultrafiltration and effect on solvent extraction, Bioproc. Biosys. Eng., 21, 157-163.

4. Wang W., Weber M.E. and Vera J.H., 1995, Reverse micellar extraction of amino acids using dioctydimethylammonium chloride, Ind. Eng. Chem. Res., 34, 599-606.

5. Tessier L., Bouchard P. and Rahni M., 2005, Separation and purification of benzylpenicillin produced by fermentation using coupled ultrafiltration and nanofiltration technologies, $J$. Biotech., 116, 79-89.

6. Hano T., Michiaki M. and Takaaki O., 1994, Continuous extraction of penicillin G with liquid surfactant membrane using Vibro Mixer ${ }^{\circledR}$, J. Membrane Sci., 93, 61-68.

7. Naoe K., Noda K., Kawagoe M. and Imai M., 2004, Higher order structure of proteins solubilized in AOT reverse micelles, Coll. Surf. B., 38, 179-185.

8. Ono T., Goto M., Nakashio F. and Hatton T.A., 1996, Extraction behaviour of haemoglobin using reversed micelles by dioleyl phosphoric acid, Biotechnol. Prog., 12, 793-800.

9. Ichikawa S., Imai M. and Shimizu M., 1992, Solubilizing water involved in protein extraction using reversed micelles, Biotechnol. Bioeng., 39, 20-26.

10. Kinugasa T., Kondo A., Mouri E., Ichikawa S., Nakagawa S., Nishii Y., Watanabe K. and Takeuchi H., 2003, Effects of ion species in aqueous phase on protein extraction into reversed micellar solution, Sep. Purif. Tech., 31, 251-259.

11. Kyung H.N. and Jee Y.I., 2005, One-step separation of lysozyme by reverse micelles formed by the cationic surfactant, cetyldimethylammonium bromide, Food Chem., 93(1), 95-101.

12. Hu Z. and Gulari E., 1996, Extraction of aminoglycoside antibiotics with reverse micelles, J. Chem. Technol. Biotechnol., 65, 45-48.

13. Carlson A. and Nagarajan R., 1992, Release and recovery of porcine pepsin and bovine cymosin from reverse micelles: A new technique based on isopropyl alcohol addition, Biotechnol. Prog., 8, 85-90. 
14. Chang Q.L., Chen J.Y., Zhang X.F. and Zhao N.M., 1997, Effect of the cosolvent type on the extraction of a-amylase with reversed micelles: Circular dichroism study, Enz. Microb.

Technol., 20, 87-92.

15. Pileni M.P., 2006, Reverse micelles used as templates: A new understanding in nanocrystal growth, J. Exp. Nanosci., 1(1), 13-27.

16. Bong K.L, Dong P.H, Sung S.L. and Kuboi R., 2004, Analysis of protein back-extraction processes in alcohol-and carboxylic acid-mediated AOT reverse micellar systems based on structural changes of proteins and reverse micelles, Biochem. Eng. J., 22, 71-79.

17. Brandani V., Giacomo G.D. and Spera L., 1996, Recovery of a-amylase extracted by reverse micelles, Proc. Biochem., 31(2), 125-128.

18. Goto M., Ishikawa Y., Ono T., Nakashio F. and Hatton T.A., 1998, Extraction and activity of chymotrypsin using AOT-DOLPA mixed reversed micellar systems, Biotechnol. Prog., 14, 729734.

19. Jun G.L., Jian M.X., Rui S., Cheng L.Y. and Hui Z.L., 2004, Reverse micelles extraction of nattokinase from fermentation broth, Biochem. Eng. J. , 21, 273-278.

20. Haghtalab A. and Osfouri S., 2003, Vacancy solution theory for partitioning of protein in reverse-micellar system, Sep. Sci. Tech., 38(3), 553-569.

21. Woll J.M., Hatton T.A. and Yarmush M.L., 1989, Bioaffinity separations using reversed micellar extraction, Biotechnol. Prog., 5, 57-62.

22. Rabie, H. R., Vera, J. H., 1998, A simple model for reverse micellar extraction of proteins. Sep. Sci. Technol., 33(8), 1181-1193.

23. Ashrafizadeh S.N. and Khoshkbarchi M.K., 1998, Modelling and experimental data for the reverse micellar extraction of proteins using a new surfactant, Sep. Sci. Technol., 33(16), 25792595.

24. Bruno P., Caselli M., Luisi P.L., Maestro M. and Traini A., 1990, A simplified thermodynamic model for protein uptake by reverse micelles: Theoretical and experimental results, J. Phys. Chem., 94(15), 5908-5917.

25. Brandani S., Brandani V. and Giacomo G.D., 1994, A thermodynamic model for protein partitioning in reverse micellar systems, Chem. Eng. Sci., 49(21), 3681-3686.

26. Leodidis E.B. and Hatton T.A., 1990, Amino acids in AOT reversed micelles. 1. Determination of interfacial partition coefficient using the phase-transfer method, J. Phys. Chem., 94: 64006411.

27. Woll J.M. and Hatton T.A., 1989, A simple phenomenological thermodynamic model for protein partitioning in reversed micellar systems, Bioprocess Eng., 4, 193-199.

28. Naoe K., Nishino M., Ohsa T., Kawagoe M. and Imai M., 1999, Protein extraction using sugar ester reverse micelles, J. Chem. Technol. Biotechnol., 74, 221-226.

29. Dekker M., Van't Riet K., Bijsterbosch B.H., Wolbert R.B.G. and Hilhorst R., 1989, Modelling and optimization of the reversed micellar extraction of $\alpha$-amylase, AIChEJ, 35, 321-324. 
30. Pires M.J., Aires-Barros M.R. and Cabral J.M.S., 1996, Liquid-liquid extraction of proteins with reverse micelles, Biotechnol. Prog., 12, 290-301.

31. Yu C.Y., Chu Y. and Ji J.Y., 2003, Study of the factors affecting the forward and back extraction of yeast-lipase and its activity by reverse micelles, J. Coll. Int. Sci., 267, 60-64.

32. Goklen K. and Hatton T.A., 1987, Liquid-liquid extraction of low molecular weight proteins by selective solubilization in reverse micelles, Sep. Sci. Technol., 22, 831-841.

33. Jolivalt C., Minier M. and Renon H., 1993, Extraction of cytochrome $c$ in sodium dodecylbenzenesulfonate microemulsions, Biotechnol. Prog., 9, 456-461.

34. Andrews B.A., 1993, The effect of protein characteristics on their extraction in reversed micelle systems, Sep. Biotech., 3, 29-36.

35. Tzeng Y.M., Tsun H.Y and Chang Y.N., 1999, Recovery of thuringiensin with cetylpyridinium chloride using micellar-enhanced ultrafiltration process, Biotechnol. Prog., 15, 580-586.

36. Nishiki T., Sato I., Katoaka T. and Kato D., 1993, Partitioning behaviour and enrichment of proteins with reversed micellar extraction: 1 . Forward extraction of proteins from aqueous to reversed micelle phase, Biotechnol. Bioeng., 42, 596-600.

37. Kilikian B.V., Bastazin M.R., Minami, N.M., Goncalves M.R. and Junior A.P., 2000, Liquid-liquid extraction by reversed micelles in biotechnological processes, Braz. J. Chem. Eng., 17, 29-38.

38. Hu Z. and Gulari E., 1996, Protein extraction using the sodium bis (2-ethylhexhyl) phosphate (NaDEHP) reverse micellar system, Biotechnol. Bioeng., 50, 203-206.

39. Noble M.J. and Varley J., 1999, Colloidal gas aphrons generated from the anionic surfactant AOT for the separation of proteins from aqueous solution, J. Chem. Technol. Biotechnol., 74(3), 231-237.

40. Rabie H.R., Helou D., Weber M.E. and Vera J.H., 1997, Comparison of the titration and contacts methods for the water solubilization capacity of AOT reverse micelles in the presence of a cosurfactant, J. Coll. Int. Sci., 189, 208-215.

41. Wang W., Weber M.E. and Vera J.H., 1994, Effect of alcohol and salt on water uptake of reverse micelles formed by dioctyldimethyl ammonium chloride (DODMAC) in isooctane, J. Coll. Int. Sci., 168, 422-427.

42. Krieger N., Taipa M.A., Aires-Barros M.R., Melo E.H.M., Lima-Filhoc J.L. and Cabral J.M.S., 1997, Purification of the citrinum Lipase Penicillium using reversed micelles AOT, J. Chem. T ech. Biotechnol., 69, 77-85.

43. Aires-Barros M.R. and Cabral J.M.S., 1991, Selective separation and purification of two lipases from chromobacterium viscosum using AOT reversed micelles, Biotech. Bioeng., 38(11), 13021307.

44. Leodidis E.B. and Hatton T.A., 1989, Specific ion effects in electrical double layers: Selective solubilization of cations in Aerosol-OT reversed micelles, Langmuir, 5, 741-753.

45. Cheng H. and Sabatini D.A., 2001, Reverse-micellar extraction for micellar-solubilized contaminant and surfactant removal, Sep. Purif. Tech., 24, 437-449. 
46. Goto M., Ono T., Horiuchi A. and Furusaki S., 1999, Extraction of DNA by reversed micelles, J. Chem. Eng. Japan, 32(1), 123-125.

47. Naoe K., Murata M., Ono C., Kawagoe M. and Imai M., 2002, Efficacy of guanidium salts in protein recovery from reverse micellar organic media, Biochem. Eng. J., 10, 137-142.

48. Frense D., Hadtendorn R. and Ulbrich-Hofmann R., 1995, 2-modified 1,3-diacylglycerols as new surfactants for the formation of reverse micelles, Chem. Phys. Lipids, 78, 81-87.

49. Kinugasa T., Tanahashi S.I. and Takeuchi H., 1991, Extraction of lysozyme using reverse micellar solution: Distribution and extraction rates, Ind. Eng. Chem. Res., 30, 2470-2476.

50. Spirovska G. and Chaudhuri J.B., 1998, Sucrose enhances the recovery and activity of ribonuclease A during reversed micelle extraction, Biotechnol. Bioeng., 58(4), 374-379.

51. Zulauf M. and Eicke H.F., 1970, Inverted micelles and microemulsions in the ternary system $\mathrm{H}_{2} \mathrm{O} /$ aerosol-OT/isooctane as studied by photon correlation spectroscopy, J. Phys Chem., 83, 480-486.

52. Lye J.L., 1993, Kinetic studies on the extraction of proteins using reverse micelles, PhD Thesis, University of Reading, UK. 


\section{FIGURES}

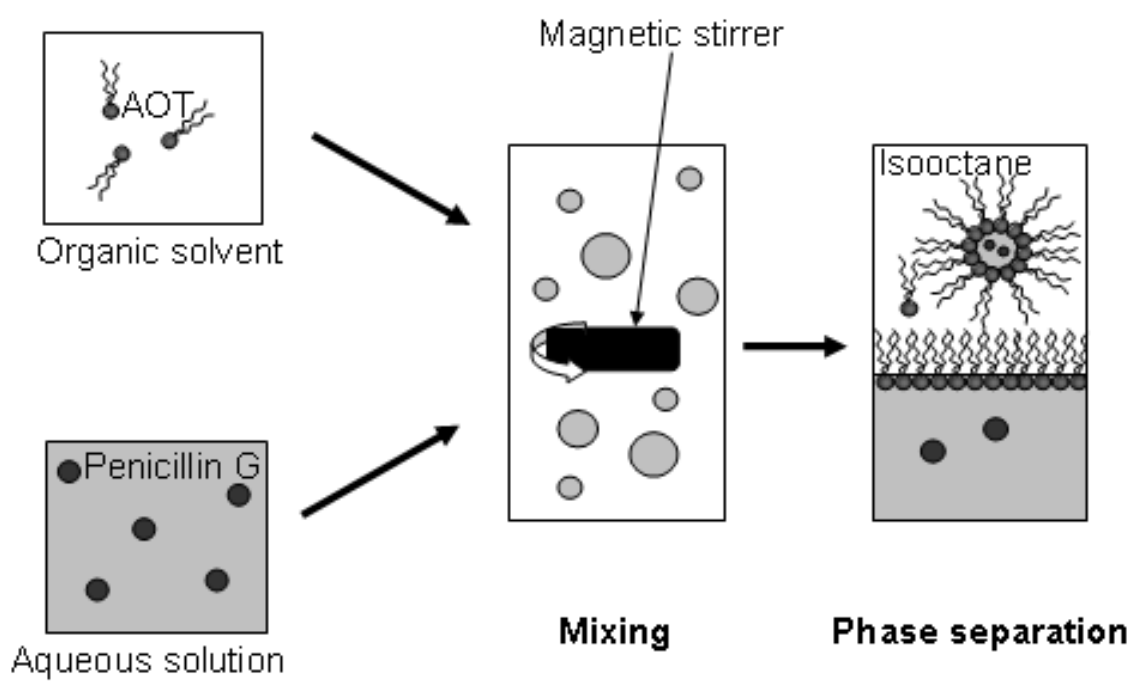

Figure 1: Diagram of the experimental procedure. Aqueous solution containing the penicillin to be extracted is contacted with an organic phase (isooctane) containing the surfactant, and then the phases are allowed to separate.

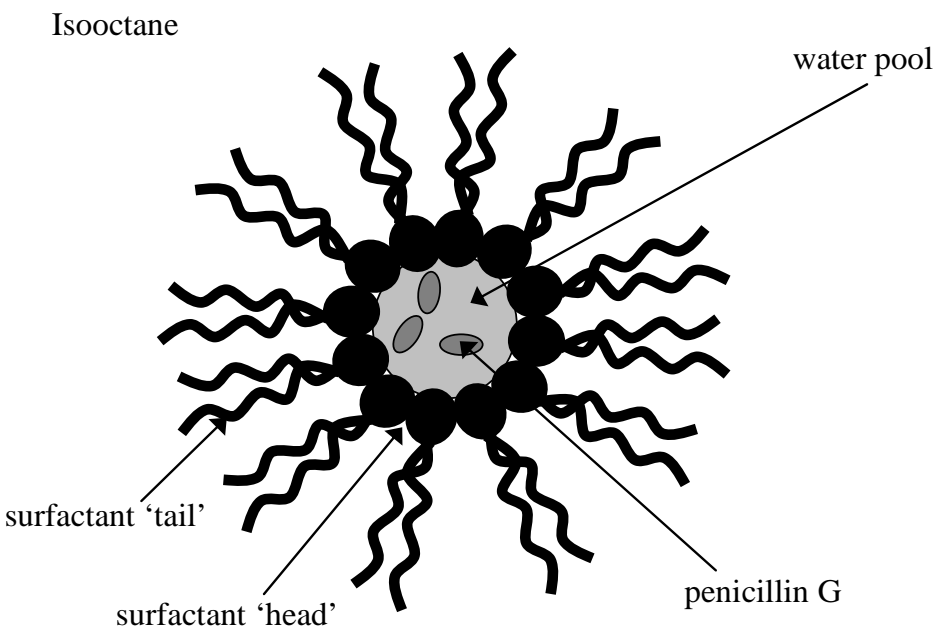

Figure 2: Schematic diagram of reverse micellar phase. The penicillin is entrapped in a water pool formed inside the reverse micelle, which itself lies in the organic (isooctane) continuous phase. 


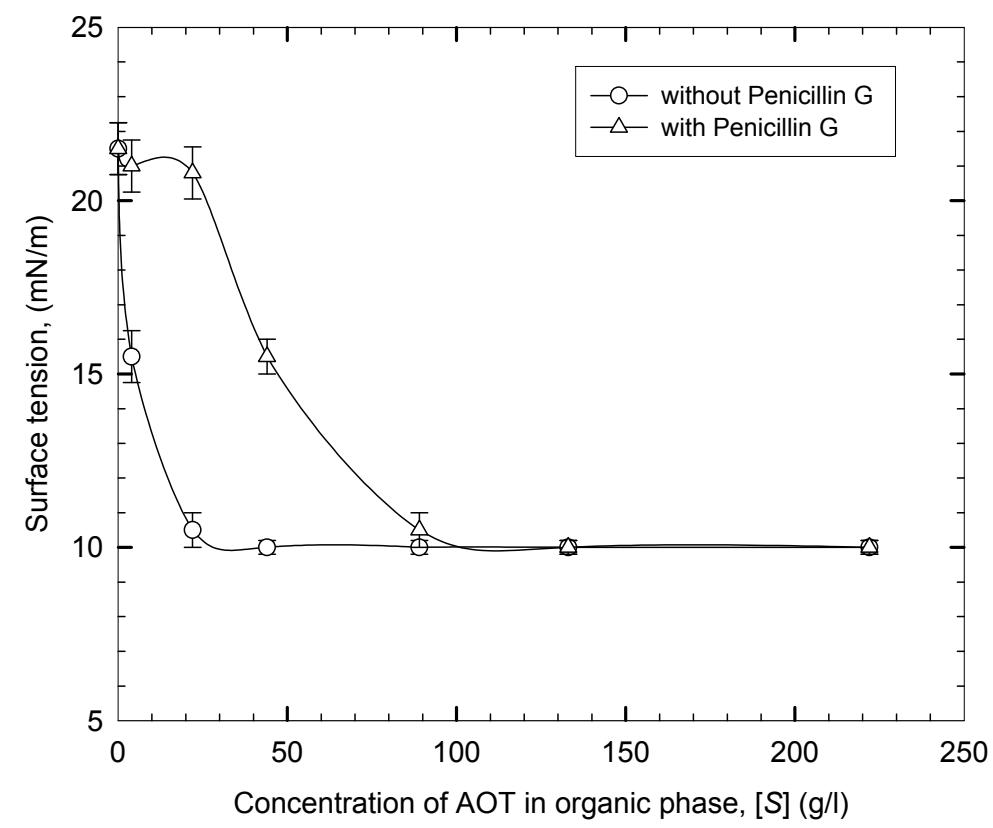

Figure 3: Effect of AOT concentration on the surface tension of isooctane with and without penicillin $\mathrm{G}$. (Initial penicillin in the aqueous phase, $3.6 \mathrm{~g} \mathrm{I}^{-1}$; $[\mathrm{KCl}]=10 \mathrm{~g} / \mathrm{l}$; temperature, $23 \pm 1^{\circ} \mathrm{C}$; stirring speed, 400 rpm for 10 minutes; $\mathrm{pH}$ 7.6).

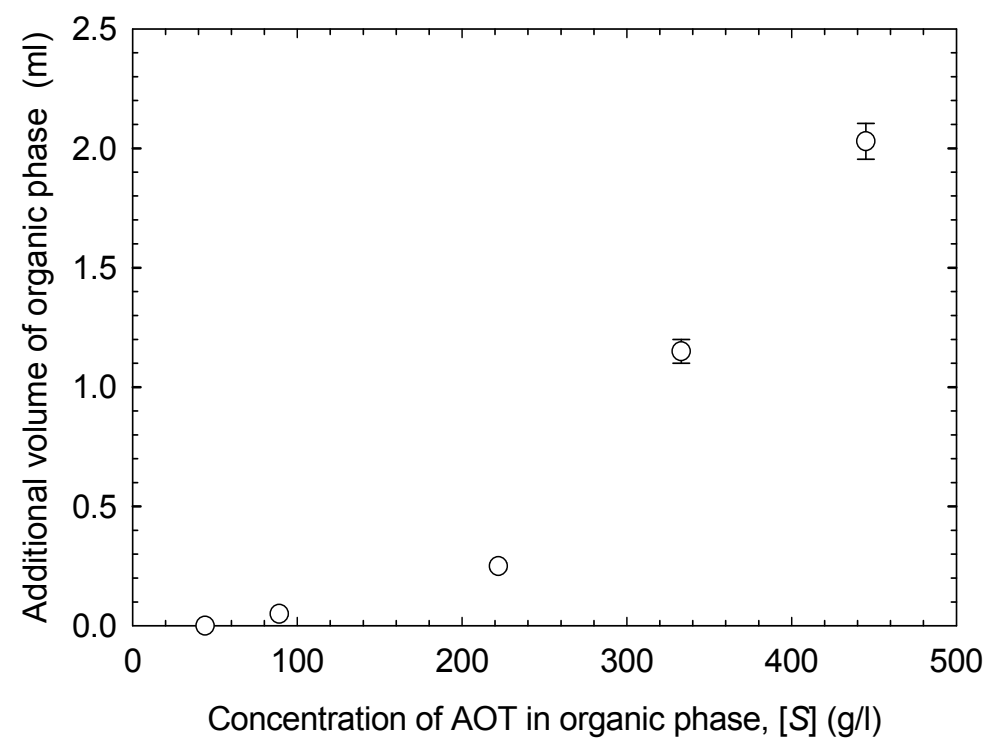

Figure 4: Additional volume of the organic phase at different AOT concentrations. (Initial volumes of the organic and aqueous phases were each $5 \mathrm{ml} ;[\mathrm{KCl}]=10 \mathrm{~g} / \mathrm{l}$; temperature, $23 \pm 1^{\circ} \mathrm{C}$; stirring speed, 400 rpm (10 min.); $\mathrm{pH} 7.6$; initial penicillin $\mathrm{G}$ concentration in the aqueous phase, $3.6 \mathrm{~g} / \mathrm{l})$. 


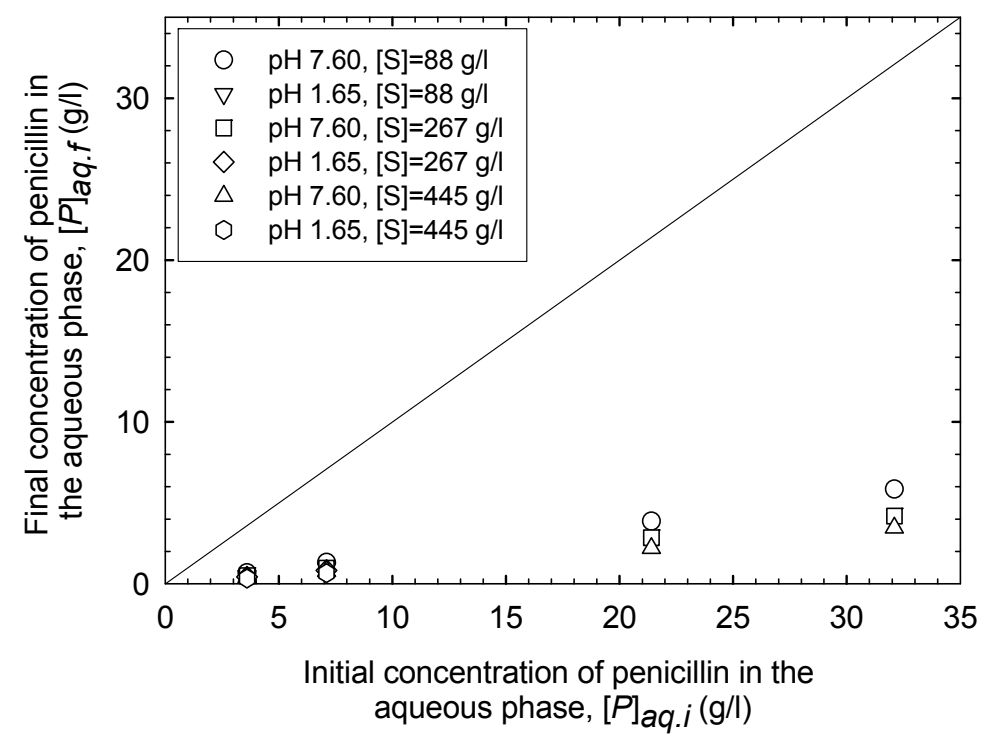

Figure 5: Final penicillin $\mathrm{G}$ concentration in the aqueous phase $\left([P]_{\text {aq.f }}\right)$ plotted against the initial penicillin $\mathrm{G}$ concentration before extraction $\left([P]_{\text {aq.i. }}\right)$ at $23^{\circ} \mathrm{C}$ and $\mathrm{KCl} 10 \mathrm{~g} / \mathrm{l}$. Deviations from the $[P]_{\text {aq.f }}=[P]_{\text {aq.i }}$ line indicate that the penicillin molecule is interfacially active.

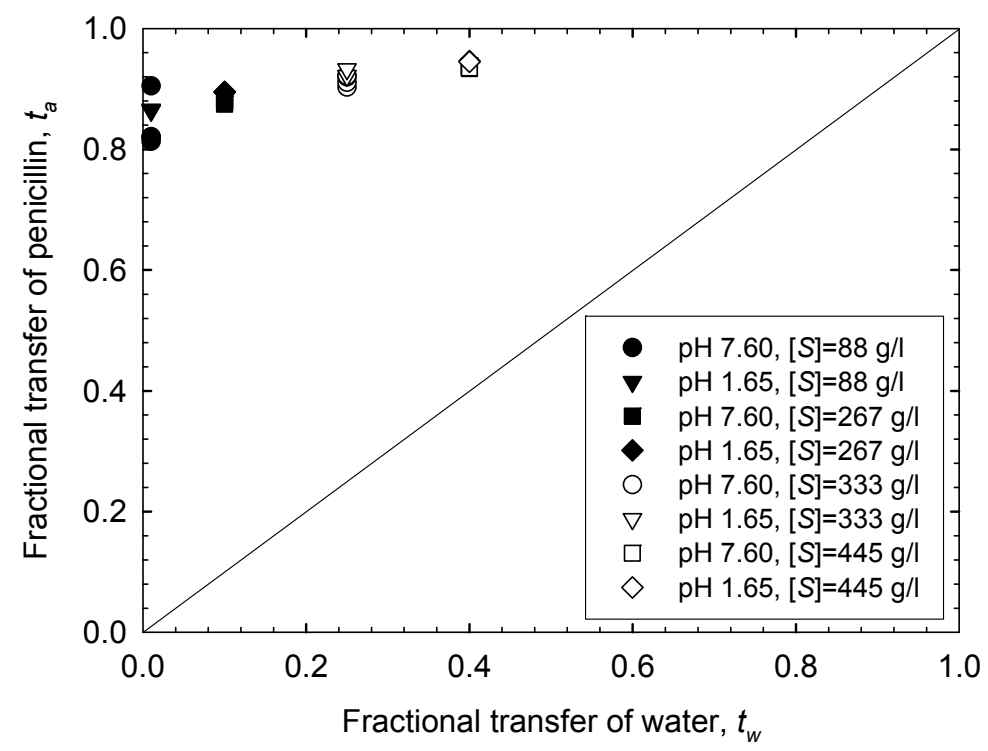

Figure 6: Fractional transfer of penicillin $\mathrm{G}\left(t_{a}\right)$ plotted against the fractional water transfer $\left(t_{w}\right)$ to the reverse micelle organic phase at different $\mathrm{pH}$ values and AOT concentrations. Deviations from the $t_{w}=t_{a}$ line are indicative that penicillin $\mathrm{G}$ is interfacially active in the presence of AOT. 


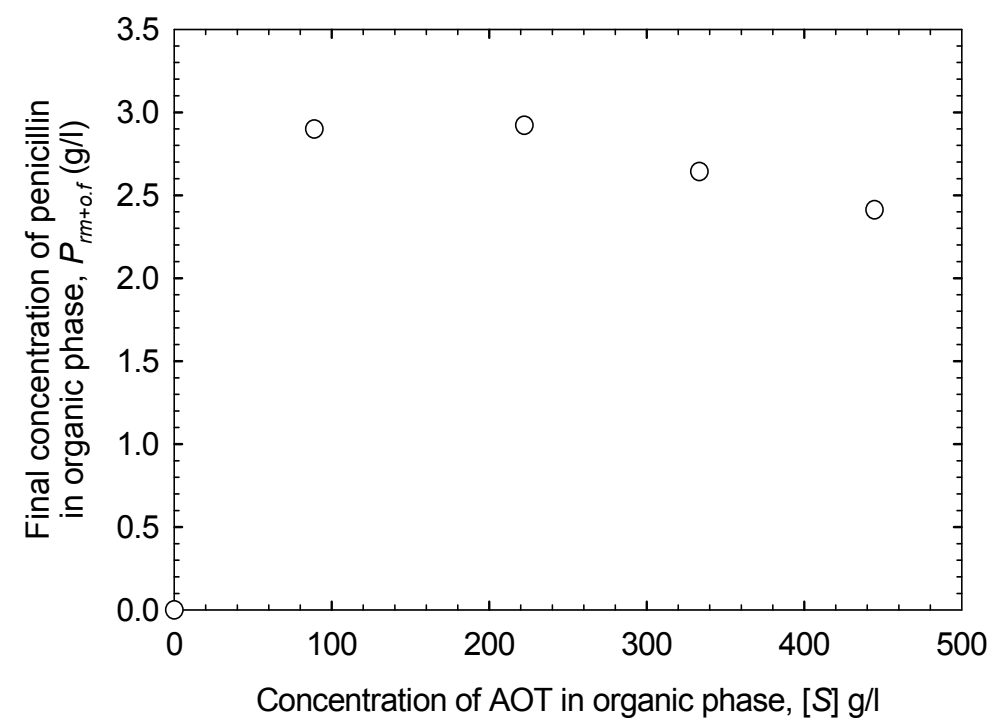

Figure 7: Concentration of penicillin $\mathrm{G}$ in the organic phase at different AOT concentrations. ([KCl] $=10 \mathrm{~g} / \mathrm{l}$; temperature $=23 \pm 1^{\circ} \mathrm{C}$; stirring speed $=400 \mathrm{rpm}(10 \mathrm{~min}$. $) ; \mathrm{pH}=7.6$; initial penicillin $\mathrm{G}$ concentration in the aqueous phase $=3.6 \mathrm{~g} / \mathrm{l})$.

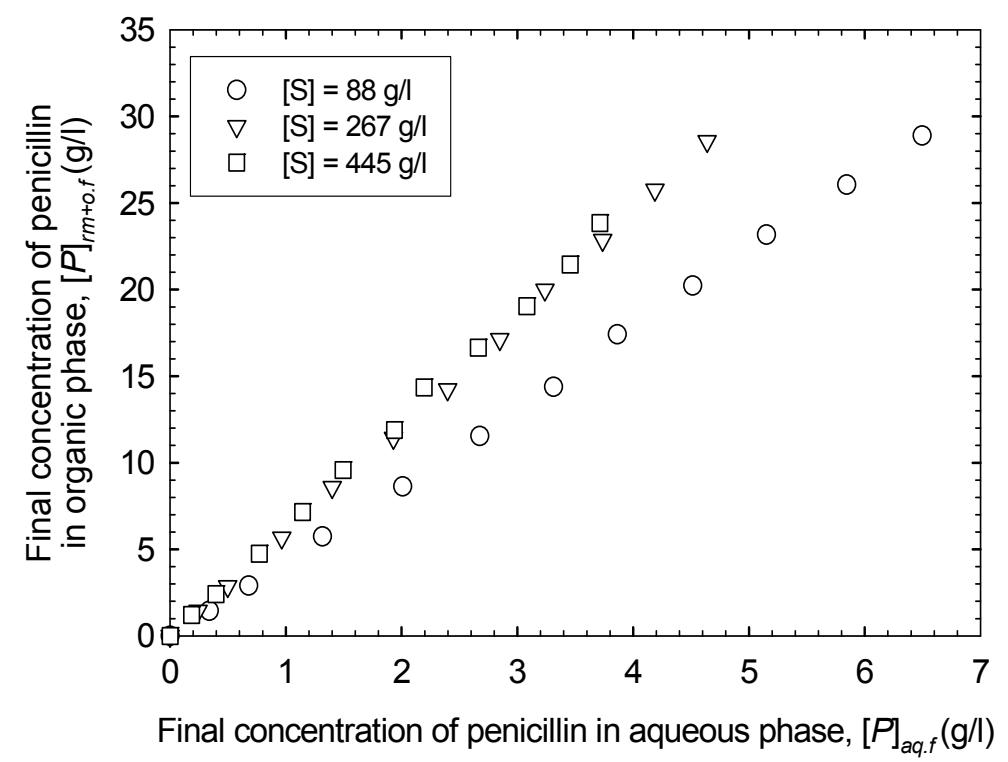

Figure 8: The distribution of penicillin $\mathrm{G}$ between the reverse micelles in the organic phase, $[P]_{r m+o . f}$ , and the aqueous phase, $[P]_{\text {aq.f. }}\left([\mathrm{KCl}]=10 \mathrm{~g} / \mathrm{l}\right.$; temperature $=23 \pm 1^{\circ} \mathrm{C}$; stirring speed $=400 \mathrm{rpm}$ (10 min.); $\mathrm{pH}=7.6$; initial penicillin $\mathrm{G}$ concentration in the aqueous phase $=3.6 \mathrm{~g} / \mathrm{l}$ ). 


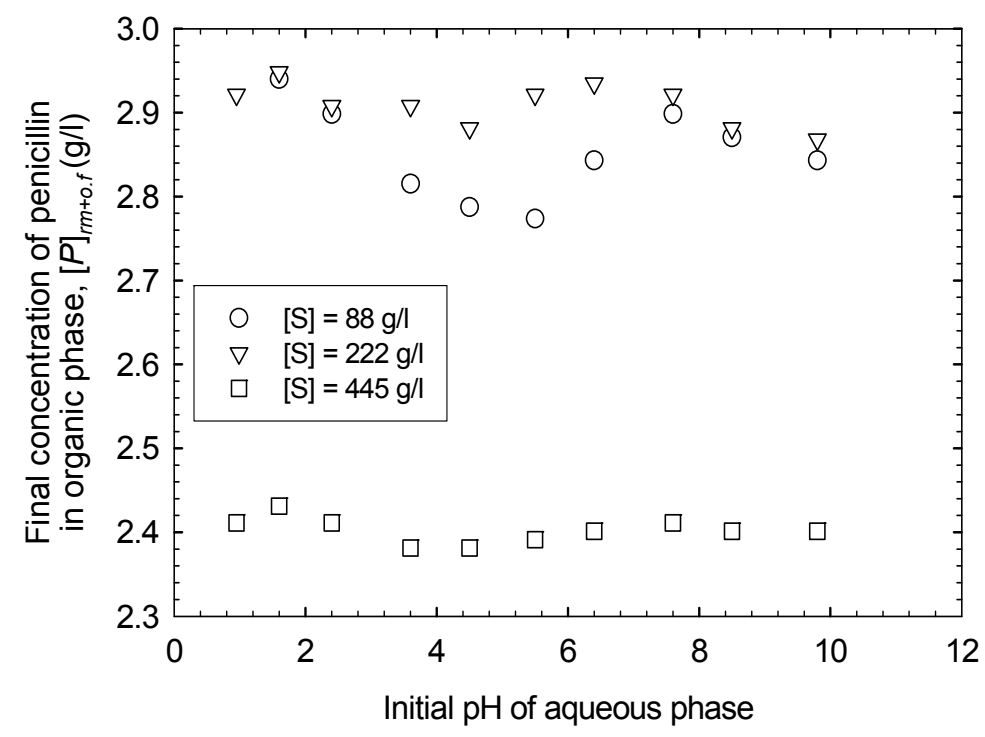

Figure 9: The effects of $\mathrm{pH}$ and AOT concentration on the amount of penicillin extracted into the micellar phases. (Temperature $=23 \pm 1^{\circ} \mathrm{C}$; stirring speed $=400 \mathrm{rpm}(10 \mathrm{~min}$.); initial penicillin $\mathrm{G}$ concentration in the aqueous phase $=3.6 \mathrm{~g} / \mathrm{l})$.

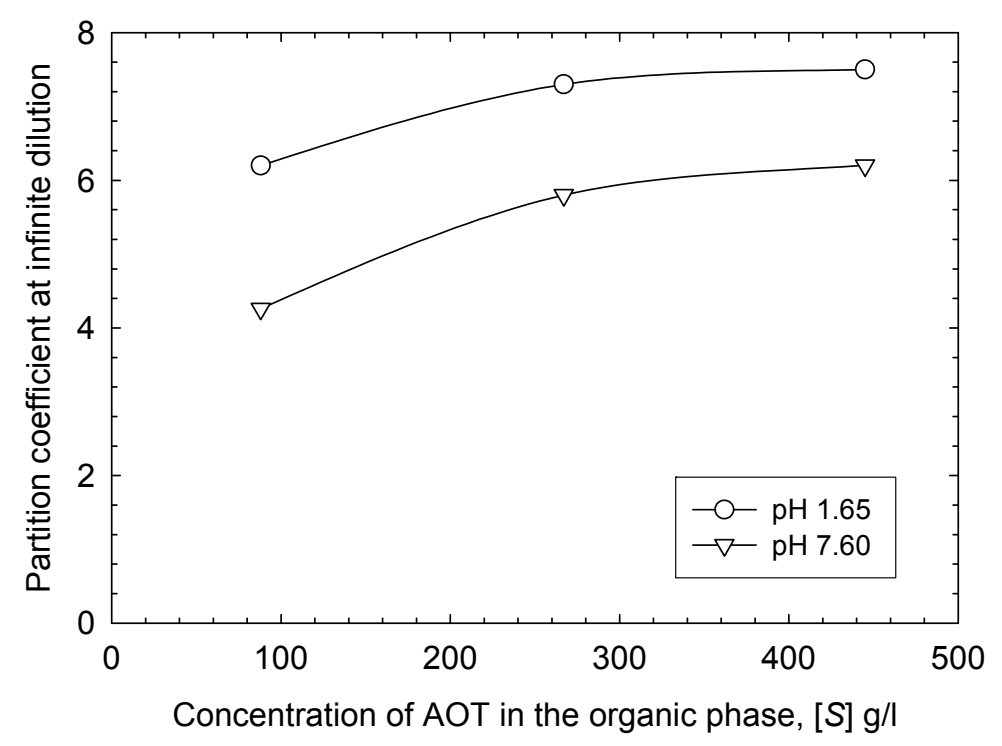

Figure 10: The variation of the partition coefficient at infinite dilution $\left(K^{\circ}\right)$ with AOT concentration and $\mathrm{pH}$. (Temperature $=23 \pm 1^{\circ} \mathrm{C}$; stirring speed $=400 \mathrm{rpm}(10 \mathrm{~min}$.); initial penicillin $\mathrm{G}$ concentration in the aqueous phase $=3.6 \mathrm{~g} / \mathrm{l})$. 

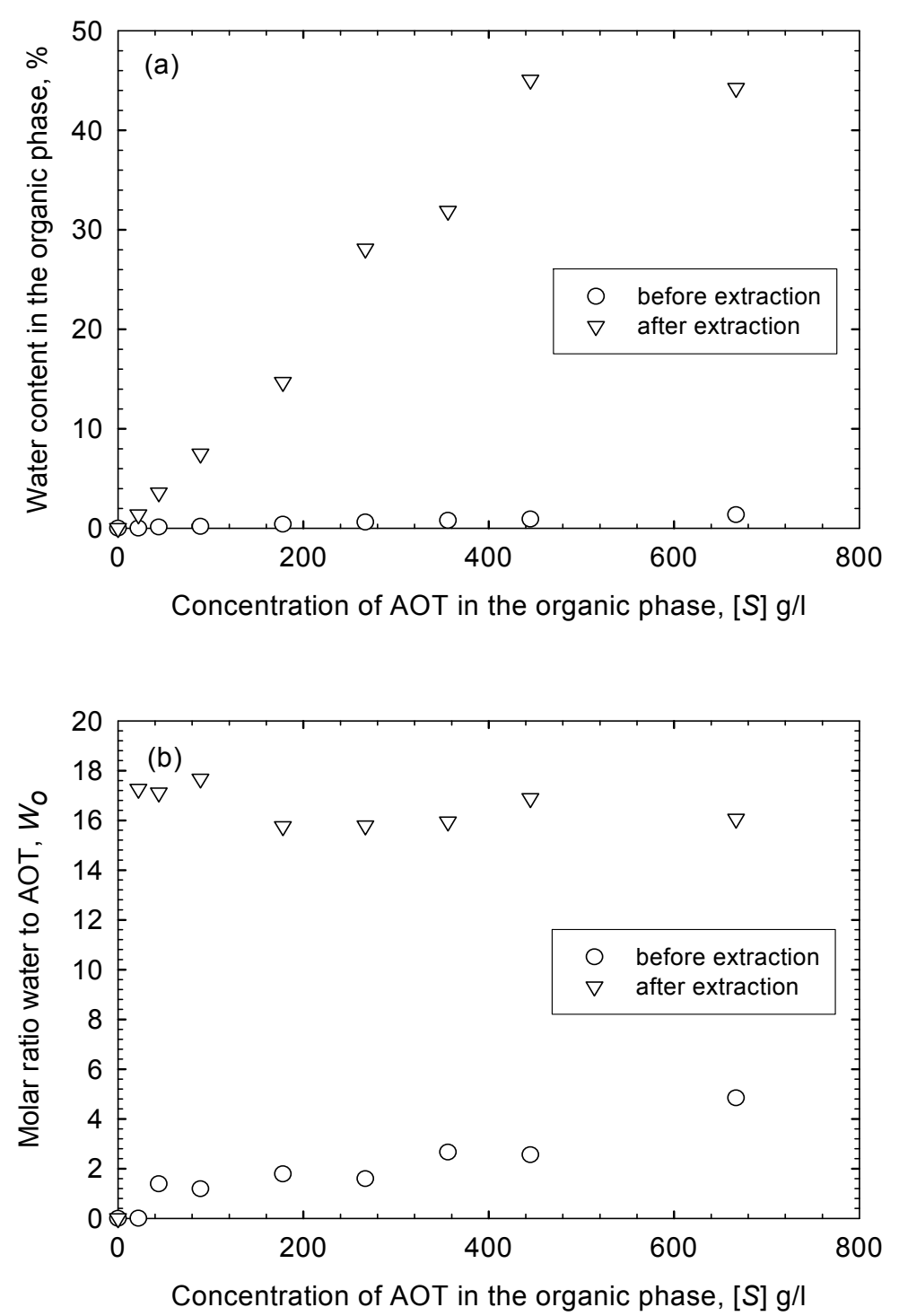

Figure 11: The effect of AOT concentration on water uptake into the reverse micelle (organic) phase presented as (a) water content, and (b) molar ratio of water to AOT, $W_{o} . \quad([\mathrm{KCl}]=10 \mathrm{~g} / \mathrm{l}$; temperature $=23 \pm 1^{\circ} \mathrm{C}$; stirring speed $=400 \mathrm{rpm}(10 \mathrm{~min}$.); $\mathrm{pH}=7.6)$. 